SCIREA Journal of Clinical Medicine

ISSN: 2706-8870

http://www.scirea.org/journal/CM

April 4, 2021

Volume 6, Issue 3, June 2021

\title{
Distribution of E23K Genotypes in Diabetic and Non-Diabetic Subjects in Port Harcourt metropolis, Nigeria.
}

\author{
Brown Holy, Enyi Alice Ruhuoma, Davies Tamunoemine \\ Department of Medical Laboratory Science, Rivers State University, Npkolu, Port Harcourt, \\ Nigeria \\ Email: hbinternational2002@yahoo.com (Brown Holy)
}

\begin{abstract}
This study examined the distribution of the E23K allele variant of the KCNJ11 gene in type 2 diabetes mellitus and non- diabetics in a Nigerian population. The E23K polymorphism of the KCNJ11 gene results from a substitution of the amino acid lysine to glutamate at codon 23. This alteration causes a critical inhibition of glucose-induced insulin secretion thereby resulting in hyperglycaemia. Hundred consenting Nigerian adults (73 diabetics and 27 nondiabetic subjects) aged at least 40 participated in this study. Genotyping was carried out with the polymerase chain reaction-restriction fragment length polymorphism (PCR-RFLP) technique using BanII restriction digestion enzyme. The restriction fragments were then electrophoresed on DNA grade agarose gel and the bands visualised using a UV transilluminator. The genotypes identified are the EE (150bp band), EK (150bp+178bp bands) and KK (178bp band) genotypes. The KK genotype was preponderant in the diabetic participants (52\%) and was followed by the EK genotype (25.9\%) while the EE genotype was more in the non-diabetic participants $(66.7 \%)$. The risks conferred by the different genotypes/allele are as follows: $\mathrm{EK}(\mathrm{p}$ value $=0.5639 ; \mathrm{OR}=1.32), \mathrm{EE}$ ( $\mathrm{p}$ value $=0.000 ; \mathrm{OR}$ $=0.21), \mathrm{KK}(\mathrm{p}$ value $=0.0037 ; \mathrm{OR}=7.03), \mathrm{K}(\mathrm{p}$ value $=0.211 ; \mathrm{OR}=2.59)$ and $\mathrm{E}(\mathrm{p}$ value $=$
\end{abstract}


0.0552 ; OR $=0.52$ ). A carrier of the KK genotype is seven times more likely than a noncarrier to develop type 2 diabetes mellitus ( $p$ value $=0.0037 ; 7.03)$. Only the KK genotype was found to significantly increase the risk of developing type 2 diabetes complications ( $p$ value $=0.02 ; \mathrm{OR}=12.67$ ). The $\mathrm{p}$ values of the selected biochemical variables are as follows: leptin $=0.95$, fasting blood sugar $=0.15, \mathrm{C}$-peptide $=0.47$, Cystatin $\mathrm{C}=0.86, \mathrm{HbA1C}=0.01$, insulin $=0.65$ and HOMA $=0.65$. Of the glycaemic variables analysed, only HbAlc showed a significant difference between the diabetic and control groups ( $\mathrm{p}$ value $=0.01$ ) but there was no significant difference in its levels in the different genotypes ( $p$ value $=0.64$ ). A significant association between the E23K polymorphism and T2DM was found in the Nigerian population that was studied. The KK genotype of the E23K polymorphism of the KCNJ11 gene is an independent predictor of Type 2 diabetes mellitus.

Keywords: E23K, Polymorphism, Diabetes Type2, Genotype, KCNJ11 gene

\section{INTRODUCTION}

Diabetes mellitus, a polygenic disorder characterized by hyperglycaemia due to pancreatic inability to secrete enough insulin or peripheral insulin resistance, has become a leading health problem worldwide (Khaled et al., 2014; Qi et al., 2012). Estimates from the International Diabetes Federation show that approximately 425 million adults were living with diabetes and this number will rise to 69 million people by 2045 . The proportion of people with type 2 diabetes is increasing in most countries with $79 \%$ of adults with diabetes living in low and middle income countries (International Diabetes Federation Atlas, 2017).

Risk factors for T2DM include family history of T2DM, age, obesity, sedentary lifestyle, hypertension and hyperlipidaemia (Taber et al., 2015). Apart from rare monogenic diabetes, type 2 diabetes mellitus is mostly a multifactorial disease resulting from the interaction of genetic variation at different chromosomal sites with environmental factors in an orchestrated manner throughout the lifespan (Permutt et al., 2005; Assman et al., 2014). Environmental factors such as changes in diet and reduction in physical activity are the most likely reasons for the marked prevalence of type 2 diabetes experienced over the last couple of decades (Vimaleswaran et al., 2010). 
Although these lifestyle changes may predispose an individual to type 2 diabetes, the disease only occurs in the presence of genetic risk factors for this condition (Vimaleswaran et al., 2010). For this reason, several genetic association studies and genome-wide association scans (GWAS) have been carried out in a bid to identify susceptibility genes and loci associated with this disease (Assman et al., 2014).

Some susceptibility genes identified by these genetic studies include TCF7L2 (Taiser et al., 2014; Nanet et al., 2015), PPARG (Mori et al.,1998; Engwa et al.,2018), SLC30A8, HHEX/IDE (Saxena et al., 2007), CDKAL1, CDKN2A/B, IGF2BP2 and FTO (Scott et al.,2007), IRSI,ADAM TS9 and GCKR ( Bossegard et al.,2009), WFS1 (Sandhu et al.,2007), HNF1B (Sparoso et al.,2008) and KCNJ11 (Lasram et al.,2014).

The KCNJ11 gene is our primary focus in this work. It is found on chromosome 11 and codes for a 390 amino acid protein that is one of the subunits of the pancreatic $\mathrm{K}_{\mathrm{ATP}}$ channel (Lasram et al., 2014; Rastegari et al., 2015).

KCNJ11 and ABCC8 genes which code for Kir6.2 and SUR1 are adjacent to each other on chromosome 11 (Sakamoto et al., 2007; Grant et al., 2009). Studies have shown that mutations in both genes cause congenital hyperinsulinism (James et al., 2009), familial persistent hyperinsulinaemic hypoglycaemia of infancy (PHHI) (Sakamoto et al., 2007), permanent neonatal diabetes (PNDM) (Sagen et al., 2004). However, these genetic studies have yielded conflicting results for $\mathrm{ABCC} 8$ variants and more consistent results for the KCNJ11 variants (Sakamoto et al., 2007).

Several single nucleotide polymorphisms (SNP) have been shown to increase susceptibility to type 2 diabetes mellitus. Thus far KCNJ11 has been found to have 219 SNPs, six of which have been linked to type 2 and they are: rs5219 (E23K polymorphism), rs5215, rs5210, rs5218, rs886288, rs2285676 (Haghvirdiazadeh et al., 2015). In the E23K polymorphism, there is a substitution of the amino acid lysine to glutamate (AAG -CAG) at codon 23 of the $\mathrm{NH}_{2}$-terminal tail of the Kir6.2 (Haghvirdiazadeh et al., 2015; Rastegari et al., 2015). Even though lysine is positively charged and glutamate carries no charge at all, there is no remarkable difference in the function and structure of the Kir6.2 proteins (Haghvirdiazadeh et al., 2015). It has been reported that the E23K variant may alter the charge of the ATPbinding region, thereby decreasing the sensitivity of the KATP channel to ATP (Haghvirdiazadeh et al., 2015). 
Similarly, this locus has been associated with increase in fasting and post prandial glucose levels (Shaat et al., 2005; Gonet et al., 2012) and higher glycated haemoglobin and blood pressure levels (Koo et al., 2007; He et al., 2008). Pharmacological studies in this polymorphism have revealed varying drug response with some patients having a better therapeutic response to glimepiride and glibenclamide than gliclazide treatment (Javorsky et al., 2012). E23K variant carriers have also been found to have a reduced response to sulfonylurea therapy (Holstein et al, 2009; El-sisi et al., 2011).

The relationship between the E23K phenotype and T2DM risk has been studied in various populations such as the European (Florez et al., 2004), Arab (Abdelhamid et al., 2014), Asian ( Zhou et al., 2009) and Tunisian populations ( Lasram et al., 2014). Significant association of E23K with T2DM was found in some European descent populations (Florez et al., 2004) and East Asian populations ( Zhou et al., 2009). In the Arabian populations, the reported results were divergent ( Abdelhamid et al., 2014) suggesting that these findings cannot be extrapolated to other populations. There is paucity of data available on the E23K allele variant in African and Nigerian populations.

There is insufficient knowledge/research in Nigeria of how genetics plays a role in the development of disease and disease progression in the different ethnic groups. Little is known of the prevalence of the $\mathrm{E} 23 \mathrm{~K}$ allele variant in the Nigerian population.

Although current diagnostic and pharmacologic practices are effective in the diagnosis and management of T2DM, they are lacking in the areas of risk prediction, determination of disease progression and individualized management (such as pharmacologic and lifestyle) therapies.

Determining the significance of E23K allele variants in T2DM patients in Port Harcourt may likely be useful in genetic risk prediction and preventive plan

\section{MATERIALS AND METHODS}

\subsection{Research Design and subject characterization}

This is a cross sectional study to identify E23k allele variants and to evaluate A1C, fasting blood sugar, leptin, Cystatin C, C-peptide, insulin and HOMA index in T2DM patients in 
Port Harcourt City. A total of 100 consenting individuals were enrolled for this study. This number was based on convenient sampling.

This study received ethical clearance from the Rivers State Health Ethics Research Committee. Participants were informed of the nature of the study and consent was obtained. The participants in this study were between 40-77 years of age: 55 males and 45 females. They were drawn from four Nigerian tribes: Ikwerre, Ijaw, Igbo and Ogoni. Seventy- three of them were diabetic and served as the test subjects while twenty - seven of them were not diabetic and served as the controls.

Consenting individuals who are of Nigerian descent aged at least 40 years diagnosed with T2DM for at least one year with glycated haemoglobin level $\geq 6.5$. Individuals less than 40 years of age, who are not of Nigerian descent and pregnant.

\subsection{Sample Collection and Assays}

Ten millilitres of venous blood were collected into fluoride oxalate, EDTA and vacuum tubes: $2 \mathrm{mls}$ for fasting blood sugar, $5 \mathrm{mls}$ for PCR analysis and $3 \mathrm{mls}$ for chemistry analysis.

C-peptide, Insulin, Leptin and Cystatin C were analysed using standard ELISA technique.

Fasting blood sugar was analysed using the glucose oxidase-peroxidase method and HbA1C was analysed using the high performance liquid chromatography technique. Polymerase chain reaction was carried out using the PCR-RFLP method described by Souza et al., 2017.

The E23K target was first amplified using a set of primers, the amplicon was Restriction Enzyme (RE) digested and visualized by agarose gel electrophoresis. A 3.0\% agarose gel was prepared by adding $3.0 \mathrm{~g}$ of agarose DNA grade to $100 \mathrm{ml}$ of $0.5 \mathrm{x}$ TBE (Tris Borate EDTA) buffer, swirling to dissolve and melting in a microwave for 3 minutes. While the mixture was cooling outside, $20 \mu 1$ of Ethidium Bromide was added. The molten agarose was poured into trays with cassettes and allowed to cool. Ten microlitres of RE digested product was loaded into each well. Electrophoresis was done at $100 \mathrm{~V}$ for 30 minutes. The gel was visualized in the UV transilluminator and pictures taken using the Genomemini Gel Documentation System. The bands observed after electrophoresis were interpreted thus: 178 bp band only represents the KK genotype, 178 bp + 150 bp bands represents the EK genotype and $150 \mathrm{bp}$ band only represents the EE genotype. 


\subsection{Statistical Analysis}

The statistical analysis was carried out using GraphPad Prism Version 8 by GraphPad Software Inc., California.

\section{Results}

\subsection{Demographic Characteristics of Participants in this Study}

The details of the demographic characteristics of the participants of this study are shown in table 1. There were 55 males and 45 females drawn from four ethnic groups (Igbo, Ijaw, Ikwerre and Ogoni). The frequencies of these ethnic groups were 30, 26, 18 and 26 respectively. Among the study population, 74 participants were on drugs while 26 were not on drugs, 20 consumed alcohol while 80 did not, 3 were smokers while the remaining 97 were non-smokers, 64 did some form of exercise while 36 did not and 55 had a family history of diabetes while 45 did not.

Table 1: Demographic characteristics of participants in this study

\begin{tabular}{|c|c|c|c|}
\hline Variable & & Number & Frequency \\
\hline & Male & 55 & 55 \\
\hline \multicolumn{4}{|l|}{ Sex } \\
\hline & Female & 45 & 45 \\
\hline & Igbo & 30 & 30 \\
\hline \multirow[t]{4}{*}{ Tribe } & Ijaw & 26 & 26 \\
\hline & Ikwerre & 18 & 18 \\
\hline & Ogoni & 26 & 26 \\
\hline & Yes & 74 & 74 \\
\hline \multicolumn{4}{|l|}{ Drugs } \\
\hline & No & 26 & 26 \\
\hline & Yes & 20 & 20 \\
\hline \multicolumn{4}{|l|}{ Alcohol } \\
\hline & No & 80 & 80 \\
\hline & Yes & 3 & 3 \\
\hline \multicolumn{4}{|l|}{ Smoking } \\
\hline & No & 97 & 97 \\
\hline
\end{tabular}


Yes

Exercise

\subsection{Anthropometric Characteristics of Participants}

Table 2 shows the mean, median, standard deviation and range values of the anthropometric characteristics of the participants. The age range of the participants was 35-77 years, the mean was $59.4 \pm 10.1$ years and the median age was 66 years. The range for duration of illness (months) was 0-30 months; the mean was $10.6 \pm 9.3$ months and median 10.0 months. The participants weighed between 38.0 and $126.0 \mathrm{~kg}$, the mean weight was $76.5 \mathrm{~kg} \pm 15.3$ and their median weight was $74.0 \mathrm{~kg}$. The mean and standard deviation of height was $1.6 \pm 0.1$, range was 1.1-1.9 and median height was 1.7. Waist circumference was between 28.0 $53.0 \mathrm{~cm}$, the mean and standard deviation was $40.6 \pm 4.6$ and median weight of $41.0 \mathrm{~cm}$. The mean BMI was $23.5 \pm 4.3$, range was between $5.4-37.1$ and the median BMI was 23.1. The systolic pressure of the participants ranged between $99.0-184.0 \mathrm{mmHg}$, the median value was $130.0 \mathrm{mmHg}$ and the mean was $132.3 \mathrm{mmHg}$. The mean for diastolic pressure was $79.0 \pm$ 11.0, the range was $58.0-107.0 \mathrm{mmHg}$ and the median diastolic pressure was $78.0 \mathrm{mmHg}$.

Table 2: Anthropometric characteristics of participants

\begin{tabular}{lcccc}
\hline Variable & Mean & SD & Median & Range \\
\hline Age (years) & 59.4 & 10.1 & 66.0 & $40.0-77.0$ \\
Duration of illness (months) & 10.6 & 9.3 & 10.0 & $0.0-30.0$ \\
Weight (kg) & 76.5 & 15.3 & 74.0 & $38.0-126.0$ \\
Height (m) & 1.6 & 0.1 & 1.7 & $1.1-1.9$ \\
Waist Circumference (cm) & 40.6 & 4.6 & 41.0 & $28.0-53.0$ \\
BMI & 23.5 & 4.3 & 23.1 & $15.4-37.1$ \\
Systolic Pressure (mmHg) & 132.3 & 17.7 & 130.0 & $99.0-184.0$ \\
Diastolic Pressure (mmHg) & 79.0 & 11.0 & 78.0 & $58.0-107.0$ \\
\hline
\end{tabular}




\subsection{Inferential Statistics on Anthropometric Data between Diabetics and Non-Diabetics}

Table 3 shows the difference in the anthropometric data between diabetic and non-diabetic participants. Mann Whitney U test was performed on anthropometric variables of diabetic and non-diabetic subjects enrolled in the study. Age had a Mann-Whitney U value of 541.0 and a $p$ value of 0.0003 . The Mann-Whitney $U$ value of weight was 720.5 and its $p$ value was 0.0589. Height was 554.0 (Mann-Whitney $U$ value) and p value was 0.0032. For waist circumference Mann-Whitney U value was 715.5 and $p$ value was 0.2547. BMI showed a Mann-Whitney U value of 895.5 and a $p$ value of 0.9212 . Systolic Pressure had a MannWhitney $U$ value of 860.0 and a $p$ value was 0.7604 . The Mann-Whitney $U$ value of diastolic pressure was 791.0 and its $\mathrm{p}$ value was 0.3772 . Only age and height showed statistically significant difference, $\mathrm{p}$ value $<0.050$.

Table 3: Inferential statistics on anthropometric data between diabetics and non-diabetics

\begin{tabular}{lcc}
\hline Variable & Mann-Whitney U value & P value \\
\hline Age (years) & 541.0 & 0.0003 \\
Weight (kg) & 720.5 & 0.0589 \\
Height (m) & 554.0 & 0.0032 \\
Waist circumference (cm) & 718.5 & 0.2547 \\
BMI & 897.5 & 0.9212 \\
Systolic Pressure (mmHg) & 860.0 & 0.7604 \\
Diastolic Pressure (mmHg) & 791.0 & 0.3772 \\
\hline
\end{tabular}

\subsection{Descriptive Statistics of Glycaemic Variables in Diabetic and Non-Diabetic subjects}

Table 4 is a descriptive statistics of the glycaemic variables between the diabetic and nondiabetic participants. It shows the mean and standard deviation of the glycaemic variables of diabetic and non-diabetic participants as well as the reference range of healthy individuals. The mean and standard deviation of insulin in the diabetic and non-diabetic subjects was 53.8 $\pm 24.8 \mathrm{miu} / \mathrm{L}$ and $55.1 \pm 22.2 \mathrm{miu} / \mathrm{L}$ respectively (reference range: $<25 \mathrm{miu} / \mathrm{L}$ ). The mean and standard deviation of leptin in the diabetic subjects was $13.9 \pm 6.3 \mathrm{ng} / \mathrm{ml}$ and in the nondiabetic it was $14.1 \pm 6.2 \mathrm{ng} / \mathrm{ml}$ (reference range: $<23.1 \mathrm{ng} / \mathrm{ml}$ ). C-peptide had a value of 3.0 $\pm 3.8 \mathrm{ng} / \mathrm{ml}$ in the diabetic participants and a value of $2.4 \pm 2.6 \mathrm{ng} / \mathrm{ml}$ in the non-diabetic participants (reference range: $0.5-2.7 \mathrm{ng} / \mathrm{ml}$ ). For $\mathrm{HbA} 1 \mathrm{C}$ it was $7.6 \pm 2.3 \%$ in the diabetic subjects and $6.5 \pm 1.6 \%$ in the non-diabetic subjects (reference range $<6.5 \%$ ). The HOMA 
index had a mean and standard deviation of $1.6 \pm 1.2$ in the diabetic participants and a mean and standard deviation of $1.4 \pm 0.5$ in the non-diabetic participants (reference range: $<2.9$ ). Fasting blood sugar was $6.5 \pm 2.1 \mathrm{mmol} / \mathrm{L}$ in the diabetic subjects and in the non-diabetic subjects it was $5.7 \pm 1.1 \mathrm{mmol} / \mathrm{L}$ (reference range: $3.4-6.8 \mathrm{mmol} / \mathrm{L}$ ). Finally, Cystatin $\mathrm{C}$ had a value of $0.8 \pm 0.4$ in the diabetic patients and a value of $0.7 \pm 0.4$ in the controls (reference range: $0.5-1.0 \mathrm{mg} / \mathrm{ml}$ ).

Table 4: Descriptive statistics of glycaemic variables in diabetic and non-diabetic subjects

\begin{tabular}{|c|c|c|c|}
\hline Variable & $\begin{array}{l}\text { Diabetic Subjects } \\
(\text { Mean } \pm \mathrm{SD})\end{array}$ & $\begin{array}{l}\text { Non-diabetic subjects } \\
(\text { Mean } \pm \mathrm{SD})\end{array}$ & $\begin{array}{l}\text { Reference Range in } \\
\text { healthy Subjects }\end{array}$ \\
\hline Insulin (miu/L) & $53.8 \pm 24.8$ & $55.1 \pm 22.2$ & $<25$ \\
\hline Leptin (ng/ml) & $13.9 \pm 6.3$ & $14.1 \pm 6.2$ & $<23.1$ \\
\hline C-peptide (ng/ml) & $3.0 \pm 3.8$ & $2.4 \pm 2.6$ & $0.5-2.7$ \\
\hline HbA1c (\%) & $7.6 \pm 2.3$ & $6.5 \pm 1.6$ & $<6.5$ \\
\hline HOMA index & $1.6 \pm 1.2$ & $1.4 \pm 0.5$ & $<2.9$ \\
\hline $\mathrm{FBS}(\mathrm{mmol} / \mathrm{L})$ & $6.5 \pm 2.1$ & $5.7 \pm 1.1$ & $3.4-6.8$ \\
\hline Cystatin C (mg/ml) & $0.8 \pm 0.4$ & $0.7 \pm 0.4$ & $0.5-1.0$ \\
\hline
\end{tabular}

\section{5 Statistical Differences in Biomarkers between Diabetic and Non-Diabetic Subjects}

Table 5 shows the test for statistical difference between diabetic and non-diabetic patients. Mann-Whitney U test was performed. The Mann-Whitney U value for leptin was 976.5 and its $\mathrm{p}$ value was 0.95 . For fasting blood sugar Mann-Whitney U value was 799.0 and the $p$ value was 0.15. C-peptide had a Mann-Whitney $U$ value of 891.0 and a $p$ value of 0.47 . Mann-Whitney U value of Cystatin C was 962.5 and its $p$ value was 0.86 . Mann-Whitney U value of $\mathrm{HbA1C}$ was 651.0 and its $\mathrm{p}$ value was 0.01 . Insulin had a Mann-Whitney $U$ value 926.5 and a $p$ value of 0.65. The Mann-Whitney $U$ value of the HOMA index was 926.0 and its $\mathrm{p}$ value was 0.65 . Only $\mathrm{HbA1C}$ showed a statistically significant difference: the rest were not statistically significant.

Table 5: Statistical differences in biomarkers between diabetic and non-diabetic subjects

\begin{tabular}{llcc}
\hline Variable & Mann-Whitney U value & P Value & Comment \\
\hline Leptin & 976.5 & 0.95 & Not significant \\
FBS & 799.0 & 0.15 & Not significant \\
\hline
\end{tabular}




\begin{tabular}{llll}
\hline C-peptide & 891.0 & 0.47 & Not significant \\
Cystatin C & 962.5 & 0.86 & Not significant \\
HBA1C & 651.0 & 0.01 & Significant \\
Insulin & 926.5 & 0.65 & Not significant \\
HOMA & 926.0 & 0.65 & Not significant \\
\hline
\end{tabular}

\subsection{Distribution of E23K Genotypes in Diabetic and Non-Diabetic Subjects}

Table 6 shows the distribution of the E23K genotypes in the diabetic and non-diabetic participants of this study as well as their Chi square and P values. A total of 28 subjects were carriers of the EE genotype (10 diabetics and 18 non-diabetic), 32 subjects had the EK genotype (25 diabetics and 7 non-diabetic) and 40 the KK genotype (38 diabetics and 2 nondiabetic). The Chi square and $p$ values for the diabetic are 5.354 and 0.0688 respectively. The $\chi^{2}$ and $\mathrm{p}$ values for the non-diabetic are 15.86 and 0004 respectively. For all the participants the $\chi^{2}$ and $p$ values are 30.00 and 0.0001 respectively.

Table 6: Distribution of E23K genotypes in diabetic and non-diabetic subjects

\begin{tabular}{|c|c|c|c|c|c|}
\hline \multirow{2}{*}{ Status } & \multicolumn{3}{|c|}{ Genotype } & \multirow{2}{*}{$\chi^{2}$ value } & \multirow{2}{*}{$\mathrm{P}$ value } \\
\hline & $\mathrm{EE}$ & EK & KK & & \\
\hline Diabetic & 10 & 25 & 38 & 5.354 & 0.0688 \\
\hline Non-diabetic & 18 & 7 & 2 & 15.86 & 0.0004 \\
\hline Total & 28 & 32 & 40 & 30.00 & 0.0001 \\
\hline
\end{tabular}

\subsection{Association of E23K Genotype to Type 2 Diabetes}

Table 7 shows the frequency of the genotypes and alleles in the diabetic and non-diabetic patients as well as the $\mathrm{p}$ values and odds ratio using a 95\% confidence interval. The EE genotype had a frequency of $10(13.7 \%)$ in the diabetic subjects and a frequency of in the non-diabetic subjects $18(66.7 \%)$ with a $\mathrm{p}$ value of 0.0003 an odds ratio of $0.21(0.08-0.50)$. The frequency of the EK genotype in the diabetic and non-diabetic subjects are 25 (34.2\%) and $7(25.9 \%)$ respectively with a $p$ value of 0.5639 and an odds ratio of $1.32(0.51-3.41)$. In the diabetic subjects the KK genotype had a frequency of $38(52.1 \%)$ and a frequency of 2 (7.4\%) in the non-diabetic subjects with a $\mathrm{p}$ value of 0.037 and an odds ratio of 7.03 (1.5931.16). The $\mathrm{K}$ allele had a frequency of $63(86.3 \%)$ in the diabetics and a frequency of 9 
$(33.3 \%)$ in the non-diabetics with a $\mathrm{p}$ value of 0.0211 and an odds ratio of $2.59(1.13-5.92)$. The E allele had frequency of $35(47.9 \%)$ in the diabetics and a frequency of $25(92.6 \%)$ in the non-diabetics with a $p$ value of 0.552 and an odds ratio of $0.52(0.26-1.02)$

Table 7: Association of E23K Genotype to Type 2 Diabetes

\begin{tabular}{|c|c|c|c|c|}
\hline Genotype & Diabetic (\%) & Non-Diabetic (\%) & $P$ value & Odds ratio $(95 \% \mathrm{CI})$ \\
\hline $\mathrm{EE}$ & $10(13.7)$ & $18(66.7)$ & 0.0003 & $0.21(0.08-0.50)$ \\
\hline EK & $25(34.2)$ & $7(25.9)$ & 0.5639 & $1.32(0.51-3.41)$ \\
\hline KK & $38(52.1)$ & $2(7.4)$ & 0.0037 & $7.03(1.59-31.16)$ \\
\hline $\mathrm{K}$ allele & $63(86.3)$ & $9(33.3)$ & 0.0211 & $2.59(1.13-5.92)$ \\
\hline E allele & 35 (47.9) & $25(92.6)$ & 0.0552 & $0.52(0.26-1.02)$ \\
\hline
\end{tabular}

\subsection{Gel bands of RE Digested Products}

Figure 1 shows the gel bands of the restricted enzyme digested products. Twenty samples are shown in figure 1. L is 100 base pairs (bp) DNA ladder. $178 \mathrm{bp}$ band is KK genotype, $150 \mathrm{bp}$ only is EE genotype while both together is EK genotype. For example, sample 17 is KK genotype, sample 14 is EE genotype and sample 20 is EK genotype. 


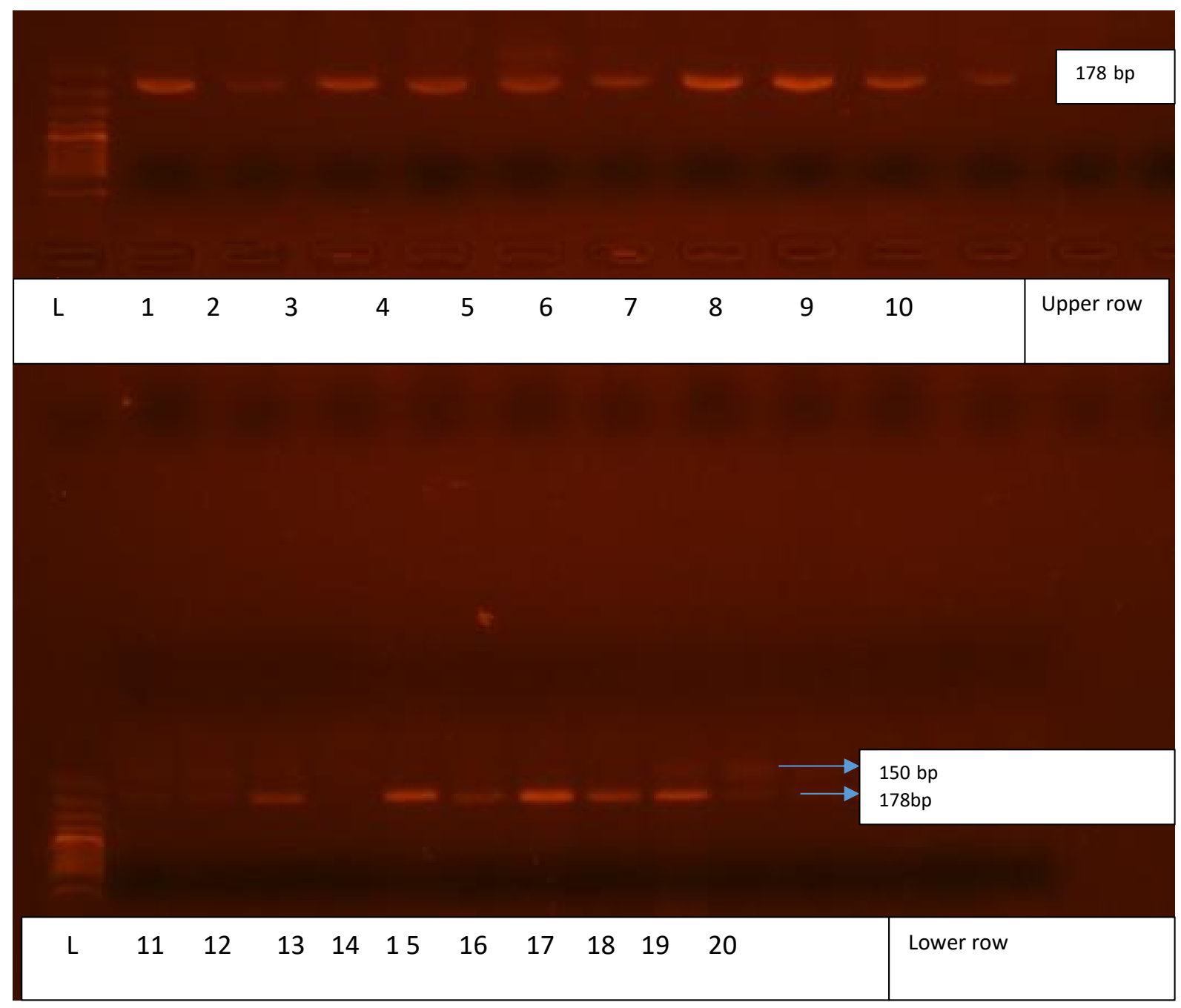

Figure 4.1: Gel bands of RE digested products

\section{DISCUSSION AND CONCLUSION}

This study examined the association between the E23K polymorphism of the KCNJII gene and type 2 diabetes mellitus in a Nigerian population.

Mann-Whitney U test was performed on the anthropometric variables of the two groups of subjects (diabetic and non-diabetic) enrolled in this study. Only age ( $p$ value $=0.0003)$ and height $(\mathrm{p}$ value $=0.0032$ ) showed a statistically significant difference at $\mathrm{p}<0.05$. Other variables including weight $(\mathrm{p}$ value $=0.0589)$, waist circumference $(\mathrm{p}$ value $=0.2547)$, BMI $(\mathrm{p}$ value $=0.9212)$, systolic pressure $(\mathrm{p}$ value $=0.7604)$ and diastolic pressure $(\mathrm{p}$ value $=$ 0.3772) did not show any significant difference. Zadhoush et al., 2015 found no significant difference between diabetic patients and control with respect to age, weight, hip circumference, waist circumference, BMI and diastolic blood pressure. 
A comparison between the levels of selected biochemical variables present in the diabetic and non-diabetic subjects (Table 4.5) showed that only HbAlc had a significant difference ( $\mathrm{p}$ value $=0.01)$. Leptin $(\mathrm{p}$ value $=0.95), \mathrm{C}$-peptide $(\mathrm{p}$ value $=0.47)$, cystatin $\mathrm{C}(\mathrm{p}$ value $=0.86)$, insulin $(\mathrm{p}$ value $=0.65)$ and HOMA $(\mathrm{p}$ value $=0.65)$ were not statistically significant. Souza et al., (2017) found that HbAlc medians were significantly higher in T2DM patients than the control group ( $\mathrm{p}$ value $=0.001$ ). The reason for this may be due to the fact that while other variables show the levels present in the participants at the time of sampling, HbAlc measures glycaemic control over the past 3 months. Also, the diabetic participants in the study were mostly people who were managing the disease with drugs and lifestyle interventions. In a study by Zadhoush et al., 2015 biochemical changes in the diabetic group without metabolic syndrome (group 1) were found to be statistically insignificant when compared with the control group but were significant when the diabetic group with metabolic syndrome (group 2) was compared with the control group. This suggests that poor disease management is associated with abnormalities in plasma parameters.

The KK genotypes were preponderant in the diabetic participants $(52 \%)$ compared the nondiabetic participants (7.4\%). From our study, having a KK genotype increases risk of T2DM by seven fold (OR =7.03, 95\% Cl: 1.59 -31.16). Similarly, Chistiakov et al., (2008) and Rastegari et al., (2015) found that people with this homozygous genotype had more risk of T2DM with $\mathrm{P}$ values of 0.004 and 0.016 respectively. The $\mathrm{K}$ allele was more predominant in the diabetic subjects $(86.3 \%)$ than in the non-diabetic subjects (33.3\%). An increased risk of nearly 3 fold $(\mathrm{OR}=2.59,95 \% \mathrm{CI}: 1.13$ - 5.92) was found in heterozygous carriers of the $\mathrm{K}$ allele. In 2013, Asaf et al., reported that carriers of the $\mathrm{K}$ allele were more predisposed to T2DM provided other factors such as physical and environmental factors were present. This agrees with the findings of Rastegari et al., (2015) $\mathrm{p}$ value $=0.048$ and Christiakov et al., (2008) $\mathrm{p}$ value $=0.023$. Of the three genotypes the KK genotype from this study has the strongest association to risk of developing diabetes complications ( $\mathrm{p}$ value $=0.002$; OR $=$ 12.67; 95\% CI: 1.618 -99.150). This may be because substitution of the wild type E (glutamic acid) with an oppositely charged K (lysine) at position 23 in the translated protein would result in a potentially significant restructuring of the pore structure and disruption of interactions with other Kir 6.2 subunits; thus providing a basis for altered high-fidelity of the $\mathrm{K}_{\text {ATP }}$ channel, especially in the homozygous state (Yang et al., 2007). Functional studies have revealed that the KK genotype markedly reduced glucose-induced $\beta$-cell insulin release by 
inducing spontaneous over activity of the pancreatic cells leading to an increase in the ATP concentration for insulin release (Riedel et al., 2003).

The frequency of the EK genotype in this study was more in the diabetic participants $(34.2 \%)$ than in the non-diabetic participants $(25.9 \%)$ but this is not statistically significant (p value $=$ 0.5639). This is different from a study carried out in an Iranian population where it was observed that the frequency of the EK genotype was more in the non-diabetic subjects ( $p$ value $=0.049)($ Rastegari et al., 2015). However, in both studies the E allele had a higher frequency in the non-diabetic patients: $92.6 \%$ for the non-diabetic participants and $47.9 \%$ for the diabetic participants $(p$ value $=0.0552)$ in this study and a $p$ value of 0.048 for the Iranian study (Rastegari et al., 2015).

The EE genotype was found to be more in non-diabetic subjects $(66.7 \%)$ than in diabetic subjects $(13.7 \%)(\mathrm{p}$ value $=0.0003)$. Thus the $\mathrm{E}$ allele carriers $(\mathrm{OR}=0.52 ; 95 \% \mathrm{CI}: 0.26-$ 1.02) probably have a lower risk of T2DM compared with the carriers of $K$ allele $(O R=2.59$; 95\% CI: 1.13 - 5.92). This is in agreement with the work of Rastegari et al., 2015 who that state that the higher prevalence of the $\mathrm{E}$ allele in non-diabetic subjects suggests that the $\mathrm{E}$ allele confers on carriers a lower risk ofT2DM when compared with carriers of the $\mathrm{K}$ allele.

HbAlc, which is the only glycaemic variable that was statistically significant, shows no significant differences in its levels in the different genotypes ( $p$ value $=0.64$, Kruskal Wallis Test).

Although the data on the association of this polymorphism to the risk of developing T2DM is inconsistent, (Gloyn et al., 2003; Souza et al., 2017; Nielson et al., 2003; Koo et al., 2007; Alsmadi et al., 2008), this study found an association between the E23K polymorphism and the development of T2DM and this is in agreement with other studies (Zhou et al., 2009; Alsmadi et al., 2008; Abdelhamid et al., 2014; Nielson et al., 2003). The inconsistency in data may be due to the failure of some studies to detect the modest impact of individual loci, aetiological heterogeneity across populations and small sample sizes (Hirschhorn et al., 2002; Souza et al., 2017).

The susceptibility of E23K allele has a modest effect (OR 1.15) on T2DM but because it is a high frequency allele it may likely contribute more to population attributable risk (Gloyn et al., 2003; Souza et al., 2009). In addition to the risk conferred on the population by the high frequency allele of $\mathrm{E} 23 \mathrm{~K}$ is the risk conferred by environmental and physical factors like BMI which have a higher predictive value (Souza et al., 2017). A 2003 study by Nielson et 
al., reveals an association between E23K and a higher BMI values. Another study suggests that mutation in both the KCNJ11 and ABCC8 genes caused the development of T2DM in obese subjects (Souza et al., 2017). Therefore higher BMI values/obesity may account for the variations seen in the contribution of $\mathrm{E} 23 \mathrm{~K}$ to the development of $\mathrm{T} 2 \mathrm{DM}$ in different populations.

\section{Conclusion}

There is significant association between the E23K polymorphism and T2DM was found in the Nigerian population that was studied. The KK genotype of the E23K polymorphism of the KCNJ11 gene could be an independent predictor of Type 2 diabetes mellitus.

\section{References}

[1] Alsmadi, O., Al-Rubeaan, K., Wakil, S. M., Imtiaz, F., Mohamed, G., Al-Saud, H., AlSaud, N., Aldaghri, N., Mohammad, S. \& Meyer, B.F. (2008). Genetic study of Saudi diabetes (GSSD): significant association of the KCNJ11 E23K polymorphism with type 2 diabetes. Diabetes/Metabolism Research and Review, 24, 137-140. And the risk for severe sulfonylurea-induced hypoglycemia in patients with type 2 diabetes. Hormone and Metabolic Research, 41(5), 387-390.

[2] Assman, T.S., Duarte, G.C., Rheinheimer, J., Cruz, L.A., Canani, L.H. \& Crispim, D. (2014). The TCF7L2 rs7903146 (C/T) polymorphism is associated with risk to type 2 diabetes mellitus in Southern-Brazil. Brazillian Society of Endocrinology and Metabolism, 58(9), 918-25.

[3] Assmann, G., Buono, P., Daniele, A., Della Valle, E., Farinaro, E., Ferns, G. \& Misciagna, G. (2014). Functional foods and cardiometabolic diseases: International task force for prevention of cardiometabolic diseases. Nutrition, Metabolism and Cardiovascular Diseases, 24(12), 1272-1300.

[4] Chistiakov, D. A., Potapov, V. A., Khodirev, D. S., Shamkhalova, M. S., Shestakova, M. V. \& Nosikov, V. V. (2008). The KCNJ11 E23K and ABCC8 exon 31 variants contribute to susceptibility to type 2 diabetes intolerance and altered insulin secretion in 
a Russian population. Diabetes and Metabolic Syndrome Clinical Research and Review, $2,185-91$.

[5] Dupuis, J., Langenberg C., Propenko, I., Saxena, R., Soranzo, N., Jackson, A.U., Wheeler, E., Glazer, N.L., Bouatia-Naji, N., Gloyn, A.L., Lindgren, C.M., Magi, R., Morris, A.P., Randall, J., Johnson, T., Elliot, P., Rybin, D., Thorleifsson, G., Steinthorsdottir, V. \& Henneman, P. (2008). New genetic loci implicated in fasting glucose homeostasis and their impact on type 2 diabetes risk. Nature genetics, 42(5), 464

[6] El-sisi, A. E., Hegazy, S. K., Metwally, S. S., Wafa, A. M. \& Dawood, N. A. (2011). Effect of genetic polymorphisms on the development of secondary failure to sulfonylurea in egyptian patients with type 2 diabetes. Therapeutic Advances in Endocrinology and Metabolism, 2(4), 155-164.

[7] Engwa, G. A., Nwalo, F. N., Chiezey, V. O., Unachukwu, M. N., Ojo, O. O. \& Ubi, B. E. (2018). Assessment of the Pro12Ala Polymorphism in the PPAR- $\gamma 2$ Gene among Type 2 Diabetes Patients in a Nigerian Population. Journal of Clinical Medicine, 7 (4), 69-75.

[8] Ezzidi, I., Mtiraoui, N., Cauchi, S., Vaillant, E., Dechaume, A., Chaieb, M., Kacem, M.M., Alawi., W.Y., Froguel, P., Mahjoub, T. \& Vaxillare, M. (2009). Contribution of type 2 diabetes associated loci in the Arabic population from Tunisia: a case-control study. BMC Medical Genetics, 10, 33.

[9] Florez, J. C., Burtt, N., de Bakker, P. I.W., Almgren, P., Tuomi, T., Holmkvist, J., Gaudet, D., Hudson, T.J., Schaffner, S.F., Daly, M.J., Hirschhorn, J.N, Groop, L. \& Altshuler, D. (2004). Haplotype structure and genotype-phenotype correlations of the sulfonylurea receptor and the islet ATP-sensitive potassium channel gene region. Diabetes, 53(5), 1360-1368.

[10] Florez, J. C., Burtt, N., de Bakker, P. I.W., Almgren, P., Tuomi, T., Holmkvist, J., Gaudet, D., Hudson, T.J., Schaffner, S.F., Daly, M.J., Hirschhorn, J.N, Groop, L. \& Altshuler, D. (2004). Haplotype structure and genotype-phenotype correlations of the sulfonylurea receptor and the islet ATP-sensitive potassium channel gene region. Diabetes, 53(5), 1360-1368.

[11] Gloyn, A. L, Weedon, M. N., Owen, K. R., Turner, M. J., Knight, B.A., Hitman, G., Walker, M., Levy, J.C., Samson, M., Halford, S., McCarthy, M.I., Hattersley, A.T. \& Frayling, T.M. (2003). Large-scale association studies of variants in genes encoding the pancreatic beta-cell KATP channel subunits Kir6.2 (KCNJ11) and SUR1 (ABCC8) 
confirm that the KCNJ11 E23K variant is associated with type 2 diabetes. Diabetes, 52, 568-572.

[12] Gonen, M. S., Arikoglu, H., ErkocKaya, D., Ozdemir, H., Ipecki, S.H., Arslan, A, Kayis, S.A. \& Gobbakan, B. (2012). Effects of single nucleotide polymorphisms in KATP channel genes on type 2 diabetes in a Turkish population. Archives of Medical Research, 43(4), 317-323.

[13] Grant, S. F., Thorleifsson, G., Reynisdottir, I., Benediktsson, R., Manolescu, A., Sainz, J., Helgason, A., Stefansson, H., Emilsson, V., Helgadottir, A., Styrkarsdottir, U., Magnusson, K.P., Walters, G.B., Palsdottir, T., Jonsdottir, T., Gudmundsdottir, T., Gylfason., A., Saemundsdottir, J., Wilensky, R.L., Reilly, M.P., Rader, D.J., Bagger, Y., Christansen, C., Gudnason, V., Sigurdsson, G., Thorsteinsdottir, U., Gulcher, J.R., Kong, A. \& Steffansson, K. (2006) Variant of transcription factor 7-like 2 (TCF7L2) gene confers risk of type 2 diabetes. Nature Genetics, 38, 320-323.

[14] Haghvirdizadeh, P., Mohamed, Z., Abdullah, N.A., Haghvirdizadeh, P., Haerian, M.S. \& Haerian, B. S. KCNJ11: Genetic Polymorphisms and Risk of Diabetes Mellitus. (2015). Journal of Diabetes Research, 908152.

[15] Hamming, K. S. C, Soliman, D., Matemisz, L. C., Niazi, O., Lang, Y., Gloyn, A.L. \& Light, P.E. (2009). Coexpression of the type 2 diabetes susceptibility gene variants KCNJ11 E23K and ABCC8 S1369A alter the ATP and sulfonylurea sensitivities of the ATP-sensitive K (+) channel. Diabetes, 58(10), 2419-2424.

[16] He, Y.Y, Zhang, R., Shao X.Y., Hu, C., Wang, C.R., Lu, J.X., Bao, Y.Q, Jia, W.P \& Xiang, K. S. (2008). Association of KCNJ11 and ABCC8 genetic polymorphisms with response to repaglinide in Chinese diabetic patients. Acta Pharmacologica Sinica, 28 (8), 983-89.

[17] Holstein, A., Hahn, M., Stumvoll, M. \& Kovacs, P. (2009). The E23K variant of KCNJ11 International Diabetes Federation Atlas. (2017). IDF Diabetes Atlas. 7th ed. International Diabetes Federation, Brussels, Belgium.

[18] James, C. Kapoor, R.R., Ismail, D. \& Hussain, K. (2009). The genetic basis of congenital hyperinsulinism. Journal of Medical Genetics, 46 (5), 289-99.

[19] Javorsky, M., Klimcakova, L., Schroner, Z., Zidzik, J., Babjakova, E., Fabianova, M., Kozarova, M., Tkacova, R, Salagovic, J. \& Tkac, I. (2012). KCNJ11 gene E23K variant 
and therapeutic response to sulfonylureas. European Journal of Internal Medicine, 23(3), 245-249.

[20] Khalid, A., Balushi, A., Mahmod, A.H, Ibrahim, A.L. \& Mohammed, A.Z. (2014). Glycaemic control among patients with type 2 diabetes at a primary health care centre in Oman. Primary Care Diabetes, 8(3), 239-43.

[21] Kocyigit, I., Dortdudak, S., Eroglu, E., Una, A., Sipahioglu, M. H., Berk, V., Tokgoz, B . \& Oymak, O. (2013) The E23K polymorphism of the KCNJ11 gene is associated with lower insulin release in patients with Autosomal Dominant Polycystic Kidney Disease Nefrologia, 33(6), 855-8.

[22] Koo, B. K., Cho, Y. M., Park, B. L., Cheong, H. S., Shin, H. D., Jang, H. C., Kim, S. Y., Lee, H. K. \& Park, K. S. (2007). Polymorphisms of KCNJ11 (Kir6.2 gene) are associated with type 2 diabetes and hypertension in the Korean population. Diabetic Medicine, 24, 178-186.

[23] Koo, B. K., Cho, Y. M., Park, B. L., Cheong, H. S., Shin, H. D., Jang, H. C., Kim, S. Y., Lee, H. K. \& Park, K. S. (2007). Polymorphisms of KCNJ11 (Kir6.2 gene) are associated with type 2 diabetes and hypertension in the Korean population. Diabetic Medicine, 24, 178-186.

[24] Lasram, K., Halim N. B., Hsouna, S., Kefi, R., Arfa, I., Ghazouani, W., Jamoussi, H., Benrahma, H., Ammar, S. B., Bahri, S., Barakat, A., Abid, A. \& Abdelhak, S. (2014). Evidence for Association of the E23K Variant of KCNJ11 Gene with Type 2 Diabetes in Tunisian Population: Population-Based Study and Meta-Analysis. Biomedical Research International, 265274.

[25] Mori, T., Matsumura, M., Yamada, K., Irie, S., Oshimi, K., Suda, K., Oguri, T. \& Ichinoe, M. (1998). Systemic aspergillosis caused by an aflatoxin-producing strain of Aspergillus flavus. Medical Mycology, 36 (2), 107-12.

[26] Nanfa, D., Sobngwi, E., Atogho-Tiedeu, Noubiap, J.J.N., Donfack, O.S., Mofo, E.P.M., Guewo-Fokeng, M., Metsadijo, A,N., Ngwa, E.N., Fosso, P.P., Djahemeni, E., DjokamDadjeu, R., Evehe, M.S., Aminkeng,F., Mbacham, W.F. \& Mbanya, J.C. (2015). Association between the TCF7L2 rs12255372 (G/T) gene polymorphism and type 2 diabetes mellitus in a Cameroonian population: a pilot study. Clinical and Translational Medicine, 4, 17. 
[27] Nielsen, E. M., Hansen, L., Carstensen, B., Echwald, S. M., Drivsholm, T., Glumer, C., Thorsteinsson, B., Borch-Johnsen, K., Hansen, T. \& Pedersen, O. (2003). The E23K variant of Kir6.2 associates with impaired post-OGTT serum insulin response and increased risk of type 2 diabetes. Diabetes, 52, 573-577.

[28] Permutt, M., Wasson, J. \& Cox, N. (2005). Genetic epidemiology of diabetes. The Journal of Clinical Investigation, 115, 1431-9.

[29] Qi, Q., Liang, L., Doria, A., Hu, F. B. \& Qi, L. (2012). Genetic predisposition to dyslipidemia and type 2 diabetes risk in two prospective cohorts. Diabetes, 61(3), 745-52.

[30] Rastegari, A., Rabbani, M., Sadeghi, H. M., Imani, E. F., Hasanzadeh, A. \& Moazen, F. (2015) Association of KCNJ11 (E23K) gene polymorphism with susceptibility to type 2 diabetes in Iranian patients. Advanced Biomedical Research, 4, 1.

[31] Riedel, M.J., Steckley, D.C. \& Light, P.E. (2005). Current status of the E23K Kir6.2 polymorphism: implications for type-2 diabetes. Human Genetics, 116(3) 133-45.

[32] Sagen, J.V., Raeder, H., Hathout, E., Shehadeh, N., Gudmundsson, K., Baevre, H., Abuelo, D., Phornphutkul, C., Molnes, J., Bell, G.I., Gloyn, A.L., Hattersley, A.T., Molven, A., Sovik, O. \& Njoslstad, P.R. (2004). Permanent neonatal diabetes due to mutations in KCNJ11 encoding Kir6.2: patient characteristics and initial response to sulfonylurea therapy. Diabetes, 53(10), 2713-8.

[33] Sakamoto, Y., Inoue, H., Keshavarz, P., Miyawaki, K., Yamaguchi, Y., Moritani, M., Kunika, K., Nakamura, N., Yoshikawa, T., Yasui, N., Shiota, H., Tanahashi, T. \& Itakura, M. (2007). SNPs in the KCNJ11-ABCC8 gene locus are associated with type 2 diabetes and blood pressure levels in the Japanese population. Journal of Human Genetics, 52, 781-793.

[34] Sandhu, R., Rai, S. K., Rai, G., Attri, H. \& Bawa, V. (2018). Assessment of genetic diversity among various genotypes of Brassisa Napus L. using molecular markers. Chemical Science Review and Letters, 7(26), 540-545.

[35] Saxena, R., Voight, B. F., Lyssenko, V., Burtt, N. P., de Bakker, P. I. W., Chen, H., Roix, J.J., Kaithiresan, S., Hirschhorn, J.N., Daly, M.J., Hughes, T.E., Groop, L., Altshuler, D., Almgren, P., Florez, J.C., Meyer, J., Ardlie, K., Bostrom, K.B., Isooma, B., Lettre, G., Linbald., U., Lyon., H.N., Melander, O., Newton-Cheh, C., Nilsson, P., Orho-Melander, M., Rastam, L., Speliotes, E.K., Taskinen, M.R., Tuomi, T., Guiducci, C., Berglund., A., 
Carlson., J., Gianninny, L., Hackettet, R., Hall, L., Holmkvist, J., Laurila, E., Sjogren, M., Sterner, M., Surti, A., Svensson, M., Svensson, M., Tewhey, R, Blumenstiel, B., Parkin, M, Defelice, M., Barry., R., Brodeur, W., Camarata., J., Chia, N., Fava, M., Gibbons, J., Handsaker, B., Healy, C., Nguyen, K., Gates, C., Sougnez, C., Gage, D., Nizzari. M., Gabriel., S.B., Chirn, G.W., Ma, Q., Parikh, H., Richardson., D, Ricke, D. \& Purcel, S. (2007). Genome-wide association analysis identifies loci for type 2 diabetes and triglyceride levels. Science, 316(5829), 1331-6.

[36] Scott, L. J., Mohlke, K. L., Bonnycastle, L. L., Willer, C. J., Li, Y., Duren, W. L., Erdos, M. R., Stringham, H. M., Chines, P. S., Jackson, A. U., Prokunina-Olsson, L., Ding, C.J., Swift, A.J., Narisu, N., Hu, T., Pruim, R., Xiao, R., Li, X.Y., Conneely, K.N, Riebow, N.L., Sprau., A.G., Tong, M., White, P.P., Hetrick, K.N., Barnhart, M.W., Bark, C.W., Goldstein, J.L.,Watkins, L., Xiang, F., Saramies, J., Buchanan, T.A., Watanabe, R.M., Valle, T.T., Kinnunen, L., Abecasis, GR., Pugh, E.W., Doheny, K,F., Boehnke, R.N., Tuomilehto, J., Collins, F.S. \& Boehnke, M. (2007). A genome-wide association study of type 2 diabetes in Finns detects multiple susceptibility variants. Science, 316, 1341-1345.

[37] Shaat, N., Ekelund, M., Lernmark, A., Ivarsson, S., Almgren, P., Berntorp, K. \& Groop, L. (2005). Association of the E23K polymorphism in the KCNJ11 gene with gestational diabetes mellitus. Diabetologia, 48, 2544-51.

[38] Souza, S. W., Alcazar, I. P., Arakaki, P. A., Santos-Weiss, I. C. R., Alberton, D., Pitcheth, G. \& Rego, F.G.M. (2017). Polymorphism E23K (rs5219) in the KCNJ11 gene in Euro-Brazilian subjects with type 1 and 2 diabetes. Genetics and Molecular Research, 16,2 .

[39] Sparso, T., Andersen, G., Albrechtsen, A., Jorgensen, T., Borch-Johnsen, K., Sandbaek, A., Lauritzen, T., Wasson, J., Permutt, M.A., Glaser, B., Madsbad, S., Pedersen, O. \& Hansen, T. (2008) Impact of polymorphisms in WFS1 on prediabetic phenotypes in a population based sample of middle-aged people with normal and abnormal glucose regulation. Diabetologia, 51, 1646-52.

[40] Taber, J. M., Klein, W. M. P., Ferrer, R. A., Lewis, K. L., Biesecker, L. G. \& Biesecker, B. B. (2015). Dispositional optimism and perceived risk interact to predict intentions to learn genome sequencing results. Health Psychology, 34(7), 718-28.

[41] Vimaleswaran, K.S. \& Loos, R.J. (2010). Progress in the genetics of common obesity and type 2 diabetes. Expert Reviews in Molecular Medicine, 12, e7. 
[42] Yang, L., Juntti-Berggren, L., Kohler, M. \& Berggren, P.O. (2007). Glucose recruits K(ATP) channels via non-insulin-containing dense-core granules. Cell Metabolism, 6(3), 217-28.

[43] Zadhoush, F., Sadeghi, M. \& Pourfarzam, M. (2015). Biochemical changes in blood of type 2 diabetes with and without metabolic syndrome and their association with metabolic syndrome components. Journal of Research in Medical Sciences, 20(8), 763770.

[44] Zhou, D., Zhang, D., Liu, Y., Zhao, T., Chen, Z., Liu, Z., Yu, L, Zhang, .Z.F., Xu, H. \& He, L. (2009). The E23K variation in the KCNJ11 gene is associated with type 2 diabetes in Chinese and East Asian population. Journal of Human Genetics, 54, 433-435. 